\title{
Evaluation of Fire Fighters' Mental Health Symptoms and Exposure to Traumatic Events, Job Stress, and Bloodborne Pathogens
}

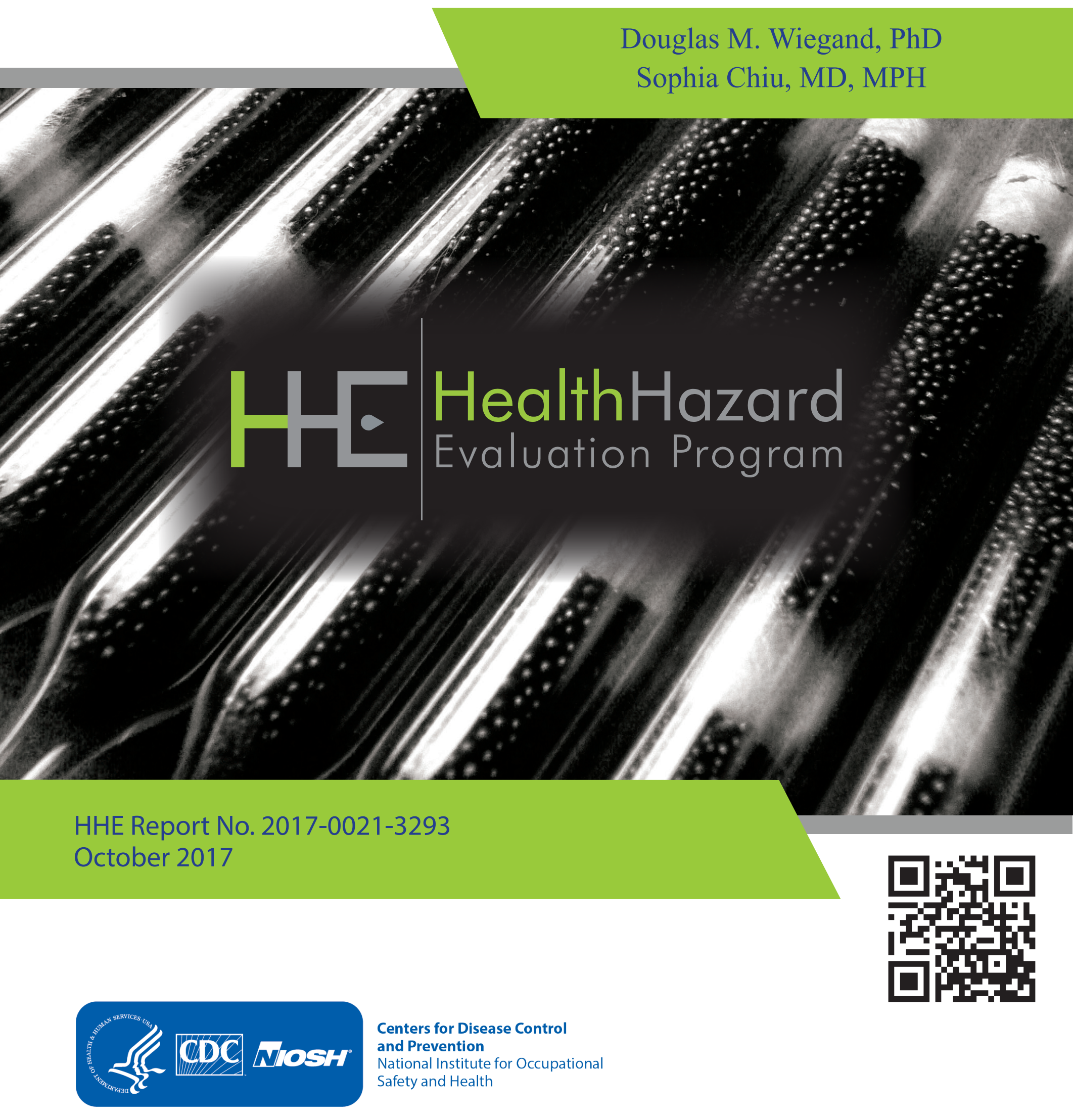




\section{Contents}

Highlights.

Abbreviations ...................................... iii

Introduction ............................................ 1

Methods ............................................. 2

Results ............................................... 3

Discussion ......................................... 11

Conclusions....................................... 13

Recommendations.......................... 14

Appendix A ........................................ 16

Appendix B .......................................... 17

References .......................................... 18

Acknowledgements......................... 23

The employer is required to post a copy of this report for 30 days at or near the workplace(s) of affected employees. The employer must take steps to ensure that the posted report is not altered, defaced, or covered by other material.

The cover photo is a close-up image of sorbent tubes, which are used by the HHE Program to measure airborne exposures. This photo is an artistic representation that may not be related to this Health Hazard Evaluation. Photo by NIOSH. 


\section{Highlights of this Evaluation}

The Health Hazard Evaluation Program received a request from a municipal fire department. The fire chief was concerned about fire fighters' mental health, job stress, and exposure to bloodborne pathogens and used needles as a result of the fire department's increased volume of drug overdose responses.

\section{What We Did}

- We visited the fire department and observed workplace conditions in April 2017.

- We administered questionnaires to fire fighters that asked about job stress, exposure to traumatic events, mental health symptoms, training and resources for coping with stress, and perceived stigma and barriers to seeking care for psychological problems.

- We interviewed fire fighters about their work and health.

\section{What We Found}

- Fire fighters reported high job stress overall. The major sources of job stress were being understaffed from recent layoffs, budget cuts to the department, dissatisfaction with pay and benefits, and lack of job security.

- All fire fighters reported experiencing a variety of traumatic events at work.

- The greatest barrier to seeking mental health care is the expense.

We evaluated job stress, mental health, bloodborne pathogen exposure, and training needs among fire fighters. We found high levels of job stress and positive screenings for symptoms of post-traumatic stress disorder, depression, and anxiety. Most fire fighters reported handling used needles and administering naloxone to revive an overdosed individual. We recommended training on suicide prevention, psychological first aid, and opioids.

- Some fire fighters reported symptoms consistent with accepted case definitions of post-traumatic stress disorder, though symptoms of depression and anxiety were more common.

- Two-thirds of interviewed fire fighters reported handling used needles or sharps. All interviewed fire fighters who handled used needles or sharps reported wearing gloves when doing so.

- About $40 \%$ of interviewed fire fighters reported coming in contact with drugs in the line of duty. None reported adverse symptoms or health effects from this contact.

- About 16\% of interviewed fire fighters reported some type of potential bloodborne pathogen exposure. Most potential exposures involved body fluids coming into contact with gear or skin that was not covered. 
- Injuries caused by persons receiving naloxone and potential bloodborne pathogen exposures were not common. Most of the incidents reported to us were not reported to the fire department.

- Not all fire fighters reported receiving training on opioids and/or bloodborne pathogens.

\section{What the Employer Can Do}

- Arrange for a mental health professional to give all fire fighters an annual training or educational presentation about suicide prevention, psychological first aid, and recognizing signs of stress.

- Provide health and safety training related to opioid overdose response.

- Encourage fire fighters to report bloodborne pathogen exposure, symptoms they relate to being in contact with drugs, and injuries to their supervisors.

- Refine the bloodborne pathogen exposure control plan.

- Provide nitrile gloves for use when bloodborne pathogen exposure is possible and during potential opioid overdose response activities.

\section{What Employees Can Do}

- Seek help from a qualified health professional if symptoms of depression, anxiety, posttraumatic stress disorder, or other mental health disorders are interfering with social, occupational, or other important areas of functioning.

- Report bloodborne pathogen exposures, health effects from being in contact with drugs, and injuries caused by individuals after receiving naloxone to your supervisor right away. 


\section{Abbreviations}

CDC Centers for Disease Control and Prevention

DEA Drug Enforcement Agency

GAD Generalized anxiety disorder

HIV Human immunodeficiency virus

NFPA National Fire Protection Association

NIOSH National Institute for Occupational Safety and Health

OSHA Occupational Safety and Health Administration

PCL-5 PTSD Checklist for the Diagnostic and Statistical Manual for Mental Disorders, 5th Edition

PPE Personal protective equipment

PTSD Post-traumatic stress disorder 
This page left intentionally blank 


\section{Introduction}

The Health Hazard Evaluation Program received a request from a municipal fire department. The fire chief was concerned about the possibility of post-traumatic stress disorder (PTSD) and exposure to bloodborne pathogens and used needles as a result of the fire department's increased volume of drug overdose responses. In April 2017, we met with union and employer representatives; administered a questionnaire about job stress, exposure to traumatic events, mental health symptoms, training and resources for coping with stress, perceived stigma and barriers to seeking care for psychological problems; and interviewed fire fighters about their work and health.

In the United States, over 33,000 opioid overdose deaths occurred in 2015. This is part of a 15-year increase in overdose deaths involving prescription opioid pain relievers and a more recent surge in deaths from illicit opioids [Centers for Disease Control and Prevention (CDC) 2016b]. During this epidemic, fire fighters face new challenges such as administering naloxone, a medication that reverses the effects of opioids, and increased call volumes, which might lead to a "personal toll" on responders [Roman 2017].

This fire department is located in one of five states with the highest rates of death from drug overdose [CDC 2016b]. Over the 5-year period from 2011 to 2016, the total number of responses by this fire department each year increased from approximately 3,500 to 4,500, a $22 \%$ increase. During the same period, the number of medical-related fire department responses increased $65 \%$, from approximately 1,300 to 2,200 each year. In the summer of 2016, the fire department responded to a mass overdose event involving 26 people at the same location over several hours. Fentanyl (50-100 times stronger than morphine) and carfentanil (approximately 10,000 times stronger than morphine) have been involved in overdoses in the area. Fentanyl and related compounds can come in powder form, and the chemical identity might not be known on scene [NIOSH 2016].

At the time of the evaluation, the fire department had 88 full-time career fire fighters. The department was forced to lay off seven fire fighters earlier in the year because of budget cuts. The fire department had six fire stations. Except for the chief and three deputy chiefs, fire fighters were divided into three shifts. On each shift, fire fighters were scheduled to work 24 hours on days 1, 3, and 5 of a 9-day cycle. They were off work on days 2, 4, 6-9 of the cycle. The chief and deputy chiefs were scheduled to work 8 hours each weekday. Each fire fighter was predominately assigned to one fire station, but fire fighters could switch shifts or work overtime at other stations with supervisor approval. We timed our visit so that we could evaluate the three shifts working on 3 consecutive days.

The objectives of our evaluation were to:

1. Screen for symptoms of PTSD, depression, and anxiety using case definitions based on validated screening tools.

2. Assess whether having a positive screening for PTSD, depression, and anxiety was associated with experiencing various types of traumatic events at work.

3. Assess fire fighters' perceived job stress. 
4. Determine the prevalence of bloodborne pathogen exposures and the fire department's exposure control plan.

5. Assess whether fire fighters were exposed to drugs or powder and whether such exposures were associated with any health effects.

6. Make recommendations to improve working conditions and practices associated with fire fighters' safety and health.

\section{Methods}

\section{Review of Written Policies and Incident Records}

We reviewed the fire department's standard operating procedure for exposure to hazardous material and infectious disease. We also reviewed records for one needlestick incident that occurred in 2016.

\section{Questionnaire Design}

We invited all fire fighters working on the dates of our visit to complete a written questionnaire. The anonymous questionnaire consisted of validated scales as well as questions developed specifically for this evaluation. It focused on job stress, exposure to traumatic events at work, mental health sypmtoms, training and use of resources to cope with stress, and perceived stigma and barriers to seeking care for psychological problems. The questionnaire also included a list of local and national resources for suicide prevention and mental health care. Each section of the questionnaire is described below.

\section{Overall Job Stress}

We asked fire fighters to rate their overall level of job stress with the following survey item: "During the past week, including today, how would you rate your current job stress level on a scale from 0 (as low as it can be) to 10 (as high as it can be)?" Responses of 0-3 indicated low job stress, 4-6 indicated moderate job stress, and scores of 7 or greater indicated high job stress [Clark et al. 2011]. Fire fighters were also asked an open-ended question about what they perceived to be major job stressors. We coded these responses into major themes.

\section{Exposure to Traumatic Events and Mental Health Symptoms}

We asked fire fighters to indicate yes/no to a list of traumatic events typical to fire fighting that they may have experienced in the past 12 months. The questionnaire included validated screening instruments to assess symptoms of PTSD [Weathers et al. 2013], depression [Kroenke and Spitzer 2002], and generalized anxiety disorder (GAD) [Spitzer et al. 2006]. Standard case definitions, presented in Appendix A, were used for each of these measures to estimate the prevalence of symptoms consistent with the disorders [Kroenke and Spitzer 2002; Spitzer et al. 2006; Weathers et al. 2013]. We used the Fisher's exact test to determine whether these variables were associated with positive screenings of PTSD, depression, and anxiety. These tests were two-tailed, and statistical significance was set at $P<0.05$. Statistical analyses were performed using SPSS version 18 . 


\section{Training and Use of Resources to Cope with Mental Health Symptoms and Stress}

We asked fire fighters if they would like (very much, somewhat, not really, not at all) to receive training at work to help them (1) cope with stress and (2) recognize signs of stress in themselves and others. We also asked them to rate their level of satisfaction (very satisfied, somewhat satisfied, somewhat unsatisfied, very unsatisfied) with the amount of social support they receive at work from coworkers and supervisors.

We listed a variety of resources fire fighters could use to cope with stress or improve mental health and asked them to indicate whether they had used each resource in the past 12 months. We asked fire fighters to indicate how likely (very likely, somewhat likely, not at all likely) they would be to use each resource in the future if they had a mental health concern. We also asked (yes/no) whether they believe they are well informed about resources available to them for helping them cope with stress.

\section{Perceived Stigma and Barriers to Care for Psychological Problems}

We included two validated scales from Britt [2000] and Hoge et al. [2004] to assess stigma of psychological problems in the work environment and barriers to seeking mental health care, respectively. We asked fire fighters to rate their level of agreement with each item on a scale from 1 (strongly disagree) to 5 (strongly agree). Scores of 3 were considered neutral, while scores of 1 or 2 indicated disagreement, and scores of 4 or 5 indicated agreement.

\section{Medical Interviews}

We invited all fire fighters working during the site visit to participate in confidential, voluntary medical interviews. We did not ask fire fighters for their name. We discussed work history and practices, training, hepatitis B vaccination, personal protective equipment (PPE) use, and possible incidents involving needlesticks or other bloodborne pathogen exposure, contact with drugs, and injury by someone who received naloxone.

\section{Results}

\section{Review of Written Policies and Incident Records}
Although not under federal Occupational Safety and Health Administration (OSHA) authority, the fire department's bloodborne pathogen exposure control plan contained most elements required by the OSHA bloodborne pathogens standard [29 CFR 1910.1030]. The fire department's exposure control plan included methods of compliance, hepatitis $\mathrm{B}$ vaccination, post-exposure evaluation and follow-up, communication of hazards to employees, and recordkeeping. The exposure control plan outlined that training on infectious disease, exposure, and vaccination would be provided at the time of hire and every 2 years thereafter. The exposure control plan did not include an exposure determination, which includes a list of all job classifications and tasks or procedures with occupational exposure to bloodborne pathogens [29 CFR 1910.1030]. In addition, the exposure control plan did 
not designate one person or department responsible for its implementation. Regarding PPE, the exposure control plan specified that medical grade disposable nonlatex gloves should be worn for patient care. In addition, eye protection was required when there is potential for splashing. Both of these requirements are consistent with National Fire Protection Association Standard (NFPA) 1500, a voluntary standard on fire department occupational safety and health programs [NFPA 2007]. The version we reviewed was revised in November 2016, less than a year before our site visit.

We reviewed the injury report form and associated police records from a needlestick incident that occurred in September 2016. During the response to overdose victims, one fire fighter experienced a needlestick to the left ring finger while removing an uncapped needle from the vehicle where the victims were located. According to the police report, the fire fighter was wearing gloves and the needle did not appear to puncture the skin. The injury report form did not document any medical evaluation for the fire fighter or source person involved in the incident.

\section{Characteristics of Participating Employees}

Of the 59 fire fighters working during our evaluation, 55 (93\%) completed a questionnaire. A subset of 45 fire fighters $(76 \%)$ participated in the medical interviews. Table 1 describes the participant demographic information.

\begin{tabular}{|c|c|}
\hline Demographic characteristic & Number (\%) \\
\hline Male & $54(100)$ \\
\hline \multicolumn{2}{|l|}{ Age in years } \\
\hline $18-25$ & $2(4)$ \\
\hline $26-35$ & $14(26)$ \\
\hline $36-45$ & $31(57)$ \\
\hline $46-55$ & $7(13)$ \\
\hline \multicolumn{2}{|l|}{ Years with this fire department* } \\
\hline$<1$ & $0(0)$ \\
\hline $1-5$ & $10(19)$ \\
\hline $6-10$ & $10(19)$ \\
\hline $11-15$ & $13(25)$ \\
\hline $16-20$ & $18(34)$ \\
\hline $21-25$ & $2(4)$ \\
\hline Supervisory position & $29(54)$ \\
\hline \multicolumn{2}{|l|}{ Race } \\
\hline Asian & $1(2)$ \\
\hline Black or African American & $1(2)$ \\
\hline White & $48(89)$ \\
\hline Other & $4(7)$ \\
\hline Hispanic or Latino ethnicity & $1(2)$ \\
\hline
\end{tabular}

${ }^{*} \mathrm{n}=53$ 


\section{Questionnaire}

\section{Job Stress}

Fire fighters were asked to rate their level of job stress on a scale from 0 (as low as it can be) to 10 (as high as it can be). The average job stress score was $8.7(\mathrm{n}=54)$, indicating high job stress overall. On the basis of individual stress scores, 1 (1.9\%) fire fighter indicated low job stress, 3 (5.6\%) indicated moderate job stress, and 50 (92.6\%) indicated high job stress.

Fifty-three fire fighters responded to the open-ended question about perceived major job stressors by listing one or more job stressors. The most frequently named job stressors were being understaffed because of recent layoffs, budget cuts by the city, dissatisfaction with pay and/or benefits, and job security. Table 2 shows the frequency of reported job stressors reported by 10 or more fire fighters.

Table 2. Perceived job stressors $(n=53)$

\begin{tabular}{lc}
\hline Job stressor & Number (\%) \\
\hline Understaffing & $28(53)$ \\
Budget cuts by city & $21(40)$ \\
Job security & $19(36)$ \\
Pay/benefits & $19(36)$ \\
Concerns about leadership & $13(25)$ \\
Responses to opioid overdoses & $12(23)$ \\
\hline
\end{tabular}




\section{Exposure to Traumatic Events}

Table 3 shows the frequency and percentage of fire fighters who reported experiencing a traumatic event at work in the past 12 months.

Table 3. Number of fire fighters who reported experiencing a traumatic event at work in the past 12 months $(n=55)$

\begin{tabular}{lc}
\hline Traumatic event & Number (\%) \\
\hline Responding to emergencies involving an opioid overdose & $55(100)$ \\
Responding to more than one opioid overdose during a single shift & $55(100)$ \\
Seeing dead adults & $54(98)$ \\
Seeing injured adults & $54(98)$ \\
Seeing neglected or unaccompanied children & $54(98)$ \\
Having to revive the same person(s) from an opioid overdose more than once* & $50(96)$ \\
Seeing injured children & $50(91)$ \\
Seeing someone die in front of you† & $40(74)$ \\
Seeing dead children & $29(53)$ \\
Being in a situation where you believed you could be killed by a fire & $26(47)$ \\
Involvement in the response to the mass overdose event in 2016† & $25(46)$ \\
Being in a situation where you believed you could be killed by another person† & $22(41)$ \\
Being personally injured in a fire response & $18(33)$ \\
Having a friend or family member overdose on an opioid* & $16(31)$ \\
Being physically attacked & $14(25)$ \\
Witnessing a mass casualty event $†$ & $13(24)$ \\
Becoming ill from smoke inhalation & $8(15)$ \\
Being involved in a serious motor vehicle accident $†$ & $3(5)$ \\
Being injured by a needlestick & $1(2)$ \\
\hline$* n=52$ &
\end{tabular}

\section{Mental Health Symptoms}

\section{Post-traumatic Stress Disorder}

Fifty-three fire fighters completed the items necessary to screen for symptoms of PTSD. Of these, 7 (13\%) screened positive for possible PTSD. We used the Fisher's exact test to determine if exposure to any of the traumatic events listed in the questionnaire were associated with a positive PTSD screening. Fire fighters who had been physically attacked on the job had a significantly higher prevalence of positive PTSD screenings than those who had not been physically attacked $(P=0.01)$. No other types of traumatic events were associated with a positive PTSD screen. 


\section{Depression}

Fifty-three fire fighters completed the items necessary to screen for symptoms of depression. Of these, 25 (47\%) screened negative for depression, $16(30 \%)$ met the criterion for mild depression, $8(15 \%)$ met the criterion for moderate depression, $3(6 \%)$ met the criterion for moderately severe depression, and $1(2 \%)$ met the criterion for severe depression. Two fire fighters (4\%) reported having suicidal ideation. The questionnaire was anonymous, so we could not directly intervene with these individuals to ensure they received mental health care. However, we immediately alerted the fire chief about the suicidal ideation responses and again provided the fire chief with local and national resources for suicide prevention and mental health. We encouraged the fire chief to distribute information about these resources to all of the fire fighters.

We used the Fisher's exact test to determine if exposure to any of the traumatic events listed in the questionnaire was associated with a positive screening of depression. Fire fighters who had someone close to them (friend or family member) overdose on an opioid had a significantly higher prevalence of positive depression screenings than those who did not have someone close to them overdose $(P<0.05)$. No other types of traumatic events were associated with a positive depression screen.

\section{Generalized Anxiety Disorder}

Of the 53 fire fighters who completed the items necessary to screen for symptoms of GAD, 25 (47\%) screened negative for anxiety, 15 (28\%) met the screening criterion for mild anxiety, $11(21 \%)$ met the screening criterion for moderate anxiety, and $2(4 \%)$ met the screening criterion for severe anxiety. We used the Fisher's exact test to determine if exposure to any of the traumatic events listed in the questionnaire were associated with a positive screening of anxiety. Fire fighters who had been in a situation on the job where they believed they would be killed by another person had a significantly higher prevalence of positive anxiety screenings than those who had not been in a situation when they thought they would be killed by another person $(P<0.05)$.

\section{Training and Use of Resources to Cope with Mental Health Symptoms and Stress}

Of 54 fire fighters, 23 (43\%) reported that they would "somewhat" or "very much" like to receive training at work to help them cope with stress. Of 55 fire fighters, $33(60 \%)$ indicated they would "somewhat" or "very much" like training at work to help them recognize signs of stress in themselves and others.

Of 54 fire fighters, 46 (85\%) indicated they were "somewhat satisfied" or "very satisfied" with the amount of social support they receive from coworkers and $27(50 \%)$ reported they were "somewhat satisfied" or "very satisfied" with the amount of social support they receive from their supervisor(s).

Of 55 fire fighters, 23 (42\%) reported they believe they are well informed about resources available to them to cope with stress and mental health symptoms. 
Table 4 describes resources fire fighters may use to help them cope with stress and mental health symptoms. Seeing one's personal physician was the most frequently used resource for coping with stress and mental health, followed by a support group at work. The support group at work was not defined in the questionnaire, so it is unclear whether the fire fighters were referring to a formal group or informal social support among their coworkers.

Table 4. Use of mental health resources in past 12 months, and likelihood of resource use in the future

\begin{tabular}{|c|c|c|c|c|c|c|}
\hline \multirow[t]{2}{*}{ Resource } & & \multirow{2}{*}{$\begin{array}{l}\text { Used in past } \\
12 \text { months } \\
\text { Number (\%) }\end{array}$} & \multicolumn{4}{|c|}{$\begin{array}{l}\text { Likelihood of using resource in the future if } \\
\text { experiencing a mental health concern }\end{array}$} \\
\hline & & & & $\begin{array}{l}\text { Very likely } \\
\text { Number (\%) }\end{array}$ & $\begin{array}{c}\text { Somewhat } \\
\text { likely } \\
\text { Number (\%) }\end{array}$ & $\begin{array}{c}\text { Not at all } \\
\text { likely } \\
\text { Number (\%) }\end{array}$ \\
\hline Personal physician & $n=54$ & $14(26)$ & $\mathrm{n}=45$ & $13(29)$ & $16(36)$ & $16(36)$ \\
\hline $\begin{array}{l}\text { Support group at } \\
\text { work }\end{array}$ & $n=53$ & $7(13)$ & $n=42$ & $7(17)$ & $15(36)$ & $20(48)$ \\
\hline $\begin{array}{l}\text { Religious leader } \\
\text { outside of work }\end{array}$ & $n=53$ & $6(11)$ & $n=43$ & $8(19)$ & $14(33)$ & $21(49)$ \\
\hline $\begin{array}{l}\text { Employee } \\
\text { assistance program }\end{array}$ & $\mathrm{n}=54$ & $3(6)$ & $n=43$ & $6(14)$ & $20(47)$ & $17(40)$ \\
\hline $\begin{array}{l}\text { Support group } \\
\text { outside of work }\end{array}$ & $n=53$ & $2(4)$ & $n=42$ & $4(10)$ & $8(19)$ & $30(71)$ \\
\hline Personal therapist & $\mathrm{n}=54$ & $1(2)$ & $n=43$ & $6(14)$ & $13(30)$ & $24(56)$ \\
\hline Online support & $n=53$ & $0(0)$ & $n=40$ & $2(5)$ & $4(10)$ & $34(85)$ \\
\hline Telephone hotline & $n=53$ & $0(0)$ & $n=40$ & $2(5)$ & $3(8)$ & $35(88)$ \\
\hline
\end{tabular}

\section{Perceived Stigma and Barriers to Care for Psychological Problems}

Table 5 shows the frequency and percentage of fire fighters who responded at each level of agreement for the perceived stigma and barriers to care items. Most of the fire fighters did not perceive stigma associated with receiving mental health care, though only $61 \%$ disagreed with the statement that receiving care would be "too embarrassing." The greatest barriers to seeking mental health care were the cost of services and skepticism about whether treatment would be effective. 
Table 5. Agreement ratings for stigma and barriers to receiving mental health care items $(n=54)$

\begin{tabular}{lccc}
\hline Stigma items $(\mathrm{n}=54)$ & $\begin{array}{c}\text { Disagree } \\
\text { Number }(\%)\end{array}$ & $\begin{array}{c}\text { Neutral } \\
\text { Number (\%) }\end{array}$ & $\begin{array}{c}\text { Agree } \\
\text { Number (\%) }\end{array}$ \\
\hline I would be seen as weak & $36(67)$ & $12(22)$ & $6(11)$ \\
Members in my unit might have less confidence & $36(67)$ & $12(22)$ & $6(11)$ \\
in me & $33(61)$ & $18(33)$ & $3(6)$ \\
It would be too embarrassing & $38(70)$ & $11(20)$ & $5(9)$ \\
My unit leadership might treat me differently & $39(72)$ & $10(19)$ & $5(9)$ \\
It would harm my career & $42(78)$ & $6(11)$ & $6(11)$ \\
My leaders would blame me for the problem & Disagree & Neutral & Agree \\
\hline Barrier items (n = 53) & Number (\%) & Number (\%) & Number (\%) \\
\hline Mental health care costs too much money* & $20(38)$ & $9(17)$ & $23(44)$ \\
I do not think mental health care would be effective & $31(58)$ & $12(23)$ & $10(19)$ \\
It would be difficult to get time off work for & $39(74)$ & $5(9)$ & $9(17)$ \\
treatment & & & \\
I don't know where to get help & $38(72)$ & $8(15)$ & $7(13)$ \\
It is difficult to schedule an appointment & $40(75)$ & $8(15)$ & $5(9)$ \\
I don't have adequate transportation & $50(94)$ & $2(4)$ & $1(2)$ \\
\hline
\end{tabular}

$* \mathrm{n}=52$

\section{Medical Interviews}

\section{Work Characteristics}

Of the 45 fire fighters interviewed, 37 (82\%) fire fighters reported working 10 24-hour shifts per month, which is consistent with the fire department's shift scheduling system. Twenty-eight (62\%) interviewed fire fighters reported currently working overtime for a median of 24 hours per month (range: 12-192 hours).

According to the fire department's standard operating procedures for exposure to hazardous materials and infectious diseases, hepatitis B vaccination should be made available to all current employees within 2 months of hire unless the employee had previously received the complete three-part vaccination series, antibody testing indicated immunity, or the vaccine was contraindicated for medical reasons. Forty-one interviewed fire fighters (91\%) reported receiving the three-part hepatitis B vaccine series. Two (4\%) fire fighters who reported having worked at the fire department for more than 2 months reported not being offered the hepatitis B vaccine and were not vaccinated against hepatitis B. However, we did not have the opportunity to confirm this information against personnel records.

All interviewed fire fighters reported always wearing gloves when attending to an individual who is "down" or "unconscious." All 32 fire fighters who reported handling needles or other sharps in the past 12 months reported wearing gloves when doing so. When asked what types of gloves they wore, 26 (58\%) open-ended responses included nitrile gloves and six (13\%) included latex gloves. Other responses include gloves described by color, "medical grade," or whatever was supplied by the fire department or emergency medical services, who are 
sometimes also on-scene during opioid overdose responses. During two emergency response ride-alongs, we observed that the gloves in an open box in one emergency response vehicle were made of latex.

\section{Training}

Table 6 shows the percentage of interviewed fire fighters who reported receiving training from the fire department on various topics. Having received training ranged from $27 \%$ for "what to do if there are drugs seen on site" to $69 \%$ for "ways to reduce exposure to bloodborne pathogens on the job." According to the exposure control plan, employees are provided training on infectious disease, exposure, and vaccination topics at the time of hire and every 2 years afterwards. We were unable to obtain and review training materials or attendance records.

Table 6. Receipt of training on topics related to opioids, needlesticks, and bloodborne pathogens $(n=45)$

\begin{tabular}{lc}
\hline Training topic & $\begin{array}{c}\text { Received training } \\
\text { Number (\%) }\end{array}$ \\
\hline Ways to reduce exposure to bloodborne pathogens on the job & $31(69)$ \\
How to safely handle used needles or sharps & $23(51)$ \\
Symptoms and other properties of diseases caused by bloodborne pathogens & $23(51)$ \\
What to do if you have a needlestick or sharps injury & $23(51)$ \\
How to recognize when a person has opioid intoxication & $22(49)$ \\
What to do if there are drugs seen on site & $12(27)$ \\
\hline
\end{tabular}

\section{Incidents}

Two-thirds of interviewed fire fighters reported handling used needles or sharps within the past 12 months: 13 (29\%) reported handling them every shift, $9(20 \%)$ every week, $6(13 \%)$ every month, and $2(4 \%)$ several times with the past 12 months. During the interviews, seven $(16 \%)$ fire fighters reported some type of potential bloodborne pathogen exposure during the past 12 months. These seven fire fighters reported a range of 1 to 12 exposures in the past 12 months. Only 3 of the 7 fire fighters (43\%) reported the exposures to the fire department. None of the reported exposures involved a needlestick, although the fire fighter who reported being injured by a needlestick in the questionnaire participated in the interviews. Most of the potential exposures involved blood, vomitus, or urine coming into contact with gear or skin that was not covered.

Nineteen interviewed fire fighters $(42 \%)$ reported coming into contact with drugs as part of their job duties in the past 12 months. One fire fighter reported the number of times this occurred was too numerous to count. The other fire fighters reported a median of 11 times (range: 1 to 75 times). In general, fire fighters described moving drugs or drug paraphernalia with drug residue away from the patient with gloved hands in order to perform job duties. The drugs were in powder, liquid, or cake form, either on drug paraphernalia or in plastic bags. None reported experiencing any symptoms or health effects after coming into contact with drugs. 
Of the 32 fire fighters (71\%) who reported administering naloxone as part of their job duties in the past 12 months, all 32 used an auto-injector and 10 reported administering naloxone intranasally. Two interviewed fire fighters (4\%) reported being injured by someone after naloxone administration in the past 12 months. One fire fighter reported it occurred twice, and the other reported it occurred 10 times in the past 12 months. The incidents involved being kicked, shoved down stairs, and being shoved against a dresser. Neither reported the incidents to the fire department because injuries were reportedly minor.

\section{Discussion}

The CareerCast [2017] annual report on stressful occupations lists fire fighting as the second most stressful job in the United States, following active duty military personnel. Fire fighters are in a high-risk occupation where they put their lives in danger regularly and have a variety of life-saving duties beyond fire suppression, such as responding to medical crises, explosions, spills, and disasters. The National Institute for Occupational Safety and Health (NIOSH) defines job stress as the harmful physical and emotional responses that occur when job demands do not match the capabilities, resources, or needs of employees [NIOSH 2011]. In our evaluation, we found that $13 \%$ of fire fighters screened positive for PTSD, 53\% screened positive for depression, and 53\% screened positive for anxiety. The 12-month prevalence of these clinical disorders among U.S. adults is 3.5\% for PTSD, 7\% for depression, and 2.9\% for anxiety [American Psychiatric Association 2013]. These rates, however, cannot be directly compared with our findings because they are based on actual diagnosed cases, whereas our findings were based on a screening tool.

Fire fighting is an inherently stressful occupation where exposure to death and other traumatic events is very likely [Corneil et al. 1999], making fire fighters more prone to PTSD and other negative mental health outcomes than the general public. Corneil et al. [1999] found a $32 \%$ prevalence rate of PTSD among fire fighters in the northeastern United States, and a NIOSH [2006] health hazard evaluation found a 27\% prevalence rate of PTSD among fire fighters in New Orleans following Hurricane Katrina. There was also a 22\% prevalence rate of depression among the fire fighters in the NIOSH [2006] health hazard evaluation.

The open-ended responses in the questionnaire and the conversations we had with the fire fighters indicated their job demands greatly outweigh the resources available to them. Not only is the job inherently stressful because of the high level of risk involved, but the fire fighters are also faced with psychosocial stressors that contribute to their perceived stress levels, such as limited resources, being understaffed, and concerns about their job security, pay, and benefits. Fire fighter stress is complicated and multifaceted, as a mixture of traumatic experiences and daily working conditions such as administrative and organizational factors can affect fire fighters' mental health, job satisfaction, and morale [Beaton and Murphy 1993; Corneil et al. 1999].

Fire fighters are repeatedly exposed to potentially life threatening and traumatic situations and are at high risk for stress-related disorders, such as PTSD [Corneil et al. 1999]. PTSD symptoms usually do not begin until at least 3 months after the trauma, but in some cases, it may take many months or years after a trauma before a person experiences symptoms 
of the disorder [American Psychiatric Association 2013]. All of the fire fighters in this evaluation reported experiencing a traumatic event at work, and most of them reported experiencing multiple traumatic events. It is therefore important that fire fighters seek and give support and psychological first aid following any traumatic incident [Norwood and Rascati 2009] and listen to and observe their coworkers for any signs of abnormal behavior that may be linked to a psychological problem. Our results showed that being physically attacked on the job is a specific traumatic event that is associated with PTSD symptoms. Fire fighters who experience this type of event should speak with someone they trust shortly after the event and determine whether further assistance is necessary to help them mentally and emotionally process the event and begin to cope.

Most of the firefighters indicated they would be somewhat or very likely to use resources such as a personal physician, support group at work, religious leader, or employee assistance program if they had a mental health concern. However, more than half said they would not see a mental health therapist. Many people who experience psychological issues do not pursue treatment from a mental health specialist, mainly due to the stigma of mental illness and seeking treatment [Andrews et al. 2001; Corrigan 2004]. In our questionnaire results, we found that most of the fire fighters do not believe there is stigma in the workplace associated with receiving mental health care. However, $11 \%-33 \%$ of the fire fighters gave neutral responses to these items, making it unclear as to whether they did not have an opinion or if they were unsure of how to respond.

Our questionnaire focused on perceived stigma in the workplace for receiving mental health care. Future efforts should expand the focus to explore perceptions of stigma from society at large, from friends and family, from the fire fighting or first responder community, and the stigma one may put on oneself for receiving mental health care. Understanding potential stigma associated with receiving mental health care and support may lead to targeted interventions for improving perceptions and utilization of mental health services [Vogel et al. 2007].

Fire fighters reported the potential for bloodborne exposures as a part of their job duties. More information about the major bloodborne pathogens of concern (human immunodeficiency virus [HIV], hepatitis B virus, and hepatitis C virus) are available in Appendix B. The incidence of blood and body fluid exposures that required an emergency department visit among first responders in the early 2000s ranged from 32 to 60 per 100,000 ambulance runs, with approximately $40 \%$ of exposure considered to be at higher risk for HIV or hepatitis transmission [Leiss et al. 2006; Merchant et al. 2009]. Although few fire fighters reported actually experiencing bloodborne exposure incidents that meet the OSHA bloodborne pathogen standard's definition [29 CFR 1910.1030] during the interviews, twothirds reported handling used needles or sharps within the past 12 months, which is a risk factor for transmission [Hu et al. 1991]. In addition, a slightly higher percentage reported administering naloxone via an auto-injector, which has a retractable needle. Because rates of HIV infection and viral hepatitis are substantially higher among persons who use drugs illicitly than among persons who do not [CDC 2012, 2015a; Suryaprasad et al. 2014], used needles or sharps that fire fighters handle in the course of opioid overdose responses might be more likely to be contaminated by body fluids with bloodborne pathogens. Thus, efforts to prevent occupational transmission of bloodborne pathogens, such as hepatitis B infection vaccination, training about bloodborne pathogens, and universal precautions are important. 
Less than half of fire fighters with potential bloodborne exposures stated that they reported such incidents to the fire department. We have limited details about the one needlestick incident reported to the fire department. From the information available, the incident did not seem to be a true needlestick because the skin was not punctured. Encouraging prompt reporting of occupational bloodborne pathogen exposures by fire fighters is important because post-exposure prophylaxis for HIV and hepatitis B when indicated works best when it is started as soon as possible after exposure [CDC 2001; Kuhar et al. 2013].

Fire fighters also reported coming into contact with drugs in the course of their work. The Drug Enforcement Agency (DEA) issued a nationwide alert that fentanyl is a threat to health and public safety in 2015 [DEA 2015]. In 2016, DEA issued an additional warning that carfentanil and other fentanyl-related compounds are a serious danger to first responder personnel [NIOSH 2016]. None of the interviewed fire fighters at this fire department reported any health effects from coming into contact with drugs. However, encouraging fire fighters to report any future incidents with health effects is important. First, affected fire fighters can receive any needed medical evaluation and treatment. Second, more can be learned about how and when such exposures happen, and what steps can be taken to protect first responder health and safety.

This evaluation was subject to several limitations. The major limitation was that the interview and questionnaire responses were based on self report, and we were not able to verify responses on the basis of records such as emergency response, training, or immunization logs. A second limitation was the possibility of recall bias when the fire fighters responded to the questionnaire or interview questions. Because the questionnaire and interviews were anonymous, we were unable to clarify any responses or ask follow-up questions once the responses were analyzed. For example, we were not able to ask the fire fighter who reported a needlestick injury on the questionnaire more about the event. In addition, more fire fighters reported administering naloxone via an auto-injector with a retractable needle that is not visible on the device than reported handling used sharps and needles within the past 12 months. Finally, although responses were anonymous, the fire fighters may have felt the need to respond to the mental health section of the questionnaire in a socially desirable manner to avoid any questioning of their fitness for duty.

\section{Conclusions}

Reported job stress was high at this workplace, which the fire fighters mainly attributed to understaffing and department budget issues. More than half of the fire fighters screened positive for mild to severe depression and/or anxiety, and 13\% screened positive for PTSD. Fire fighters' job duties involved the potential for bloodborne pathogen exposure, coming into contact with opioids that can cause adverse health effects, and injuries from persons who become violent after receiving naloxone. Although exposure incidents or injuries have been uncommon, they are likely to be underreported to the fire department. Fire fighters should be trained and educated on mental health issues such as suicide prevention, psychological first aid, and recognizing signs of stress in addition to occupational safety and health topics related to opioids and bloodborne pathogen exposure. 


\section{Recommendations}

On the basis of our findings, we recommend the actions listed below. We encourage the fire department to use a labor-management health and safety committee or working group to discuss our recommendations and develop an action plan. Those involved in the work can best set priorities and assess the feasibility of our recommendations for the specific situation at the fire department.

1. Encourage employees to seek help from a qualified health professional if they are experiencing symptoms of depression, anxiety, PTSD, or other mental health disorders that are interfering with their social, occupational, or other important areas of functioning. One resource for employees is the employee assistance program at St. Mary’s Medical Center (304) 526-1234 or http://www.st-marys.org/. Employees should feel that mental health symptoms they may be experiencing are not their fault, are reversible, and will improve with proper treatment [Vogel et al. 2007].

2. Arrange for a mental health professional to give all fire fighters an annual training or educational presentation about suicide prevention, psychological first aid, and recognizing signs of stress. To supplement these trainings, the Suicide Prevention Resource Center has helpful resources at http://www.sprc.org. The National Institute of Mental Health also has resources on its suicide prevention topic page at http://www.nimh.nih.gov/health/topics/suicide-prevention/index.shtml. The American Psychological Association's stress topic page provides information and resources for recognizing and coping with stress at http://www.apa.org/topics/stress/index.aspx.

3. Inform and discuss with the fire fighters the various mental health resources available to them.

4. Provide training upon hire and at least annually thereafter on topics related to opioids, naloxone administration, and bloodborne pathogens. Periodically review training needs as job demands and occupational hazards might change over time.

5. Encourage employees to report all potential bloodborne pathogen exposure incidents, health effects from being in contact with drugs, and injuries caused by individuals immediately after they receive naloxone. Emphasize the importance of timely medical evaluation and treatment, if indicated. NIOSH has developed a publication on encouraging first responders to report bloodborne pathogen exposures, which is available at https://www.cdc.gov/niosh/docs/2008-118/pdfs/2008-118.pdf.

6. Ensure that hepatitis $B$ vaccination is made available to all fire fighters within 10 working days of initial assignment unless the fire fighter has previously received the complete hepatitis B vaccination series, antibody testing shows immunity, or the vaccine is contraindicated for medical reasons. Make hepatitis B vaccination available to fire fighters who initially declined vaccination but later decide to accept the vaccination. 
7. Include all the required elements of the exposure control plan according to the OSHA bloodborne pathogens standard as best practice. Designate a person or department responsible for implementing the exposure control plan and perform an employee exposure determination. OSHA has developed a model template that includes a guide on how to create an exposure control plan that meets the requirements in the OSHA bloodborne pathogen standard available at https:/www.osha.gov/Publications/osha3186.pdf.

8. Provide nitrile gloves for fire fighters to wear as part of universal precautions against bloodborne pathogen exposure as well as during opioid overdose response activities. Do not use latex gloves for these activities because of potential allergic reactions. More specific interim guidance on gloves use when handling fentanyl and related compounds is available at https://www.cdc.gov/niosh/topics/fentanyl/default.html. 


\section{Appendix A: Scoring Criteria for Mental Health Screening Tools}

\section{Post-traumatic Stress Disorder}

We used the U.S. Department of Veterans Affairs' PTSD Checklist for the Diagnostic and Statistical Manual for Mental Disorders, 5th Edition (PCL-5) [Weathers et al. 2013] screening tool for PTSD. We calculated a total symptom severity score (range $0-80$ ) by summing the scores of the 20 items in the measure, and used the recommended cut point of 33 and greater as a positive screen for PTSD.

\section{Depression}

We used the Patient Health Questionnaire [Kroenke and Spitzer 2002] to screen for depression. We calculated a total symptom severity score (range $0-27$ ) by summing the scores of the nine items in the measure, and used the recommended cut points for depression of 5 (mild), 10 (moderate), 15 (moderately severe), and 20 (severe).

\section{Anxiety}

We used the GAD-7 [Spitzer et al. 2006] to screen for anxiety. We calculated a total symptom severity score (range: $0-21$ ) by summing the scores of the nine items in the measure, and used the recommended cut points of 5 (mild), 10 (moderate), and 15 (severe) anxiety. 


\section{Appendix B: Bloodborne Pathogens}

\section{Human Immunodeficiency Virus}

HIV, also known as the human immunodeficiency virus, is the virus that can lead to acquired immune deficiency syndrome, or AIDS. HIV attacks part of the body's immune system by destroying specific blood cells, called CD4+ T cells, which are crucial to helping the body fight diseases. Each year, approximately 40,000 U.S. residents become infected with HIV [CDC 2016a]. In 2012, an estimated 1,218,400 persons were living with HIV, including 156,300 (12.8\%) whose infection was undiagnosed [CDC 2015b]. Through December 2013, 58 cases of occupational HIV transmission to healthcare workers in the United States were documented, and no confirmed cases have been reported since 1999 [CDC 2016c; Do et al. 2003]. The average risk for HIV transmission after a percutaneous exposure to HIV-infected blood has been estimated to be approximately 0.3\% [Bell et al. 1997; Gerberding 1994; Ippolito et al. 1999].

\section{Hepatitis B}

Hepatitis B is a contagious liver disease that results from infection with the hepatitis B virus. It can range in severity from a mild illness lasting a few weeks to a serious, lifelong illness. Effective hepatitis B vaccines have been available in the United States since 1981, and since then, the incidence of acute hepatitis B has declined. In the United States, 3,370 new cases of hepatitis B infection were reported in 2015, but it is estimated that there are approximately 6.5 times more actual new cases than reported cases. An estimated 850,000-2.2 million persons in the United States are living with chronic hepatitis B infection [CDC 2017; Kowdley et al. 2012]. The rate of hepatitis B transmission to susceptible (or non-immunized) healthcare workers ranges from $6 \%-30 \%$ after a single needlestick exposure from a hepatitis B infected patient [CDC 1997].

\section{Hepatitis C}

Hepatitis $\mathrm{C}$ is a contagious liver disease that results from infection with the hepatitis $\mathrm{C}$ virus. It can range in severity from a mild illness lasting a few weeks to a serious, lifelong illness. It more commonly causes chronic infection than hepatitis B. An estimated 2.7-3.9 million persons in the United States are chronically infected with hepatitis C. The number of acute hepatitis $\mathrm{C}$ cases in the United States was estimated to be 33,900 [Armstrong et al. 2006; CDC 2017]. The average rate of hepatitis $C$ transmission averages $1.8 \%$ for healthcare workers exposed to hepatitis $\mathrm{C}$ through a needlestick or percutaneous injury [Alter 1997; CDC 1998]. 


\section{References}

Alter MJ [1997]. The epidemiology of acute and chronic hepatitis C. Clin Liver Dis 1(3):559-569, http://dx.doi.org/10.1016/S1089-3261(05)70321-4.

American Psychiatric Association [2013]. Diagnostic and statistical manual of mental disorders, 5th ed. Arlington, VA: American Psychiatric Association, http://dsm.psychiatryonline.org/doi/book/10.1176/appi.books.9780890425596.

Andrews G, Issakidis C, Carter G [2001]. Shortfall in mental health service utilization. Brit J Psychiat 179:417-425, http://dx.doi.org/10.1192/bjp.179.5.417.

Armstrong GL, Wasley AM, Simard EP, McQuillan GM, Kuhnert WL, Alter MJ [2006]. The prevalence of hepatitis C virus infection in the United States, 1999 through 2002. Ann Intern Med 144(10):705-714, http://dx.doi.org/10.7326/0003-4819-144-10-200605160-00004.

Beaton RD, Murphy SA [1993]. Sources of occupational stress among fire fighter/EMTs and fire fighter/paramedics and correlations with job-related outcomes. Prehosp Disaster Med 8(2):140-150, https://dx.doi.org/10.1017/S1049023X00040218.

Bell DM [1997]. Occupational risk of human immunodeficiency virus infection in healthcare workers: an overview. Am J Med 102(3B):294S-300S, https://dx.doi.org/10.1093/oxfordjournals.aje.a117097.

Britt TW [2000]. The stigma of psychological problems in a work environment: evidence from the screening of service members returning from Bosnia. J Appl Soc Psychol 30(8):1599-1618, http://dx.doi.org/10.1111/j.1559-1816.2000.tb02457.x.

CareerCast [2017]. Most stressful jobs of 2017, http://www.careercast.com/jobs-rated/most-stressful-jobs-2017.

CDC [1997]. Immunization of health-care workers: recommendations of the Advisory Committee on Immunization Practices (ACIP) and the Hospital Infection Control Practices Advisory Committee (HICPAC). MMWR 46(RR-18):1-42, https://www.cdc.gov/MMWR/preview/mmwrhtml/00050577.htm.

CDC [1998]. Recommendations for prevention and control of hepatitis C virus (HCV) infection and HCV-related chronic disease. MMWR 47(RR-19):1-39, https://www.cdc.gov/mmwr/preview/mmwrhtml/00055154.htm.

CDC [2001]. Updated U.S. Public Health Service guidelines for the management of occupational exposures to $\mathrm{HBV}, \mathrm{HCV}$, and $\mathrm{HIV}$ and recommendations for postexposure prophylaxis.

MMWR 50(RR11):1-52, https://www.cdc.gov/mmwr/preview/mmwrhtml/rr5011a1.htm.

CDC [2012]. Integrated prevention services for HIV infection, viral hepatitis, sexually transmitted diseases, and tuberculosis for persons who use drugs illicitly: summary guidance from CDC and the U.S. Department of Health and Human Services.

MMWR 61(RR05):1-40, https://www.cdc.gov/mmwr/preview/mmwrhtml/rr6105a1.htm. 
CDC [2015a]. Increases in hepatitis $C$ virus infection related to injection drug use among persons aged $\leq 30$ years - Kentucky, Tennessee, Virginia, and West Virginia, 2006-2012. MMWR 64(17):453-458, https://www.cdc.gov/mmwr/preview/mmwrhtml/mm6417a2.htm.

CDC [2015b]. Prevalence of diagnosed and undiagnosed HIV infection - United States, 2008-2012. MMWR 64(24):657-662, https://www.cdc.gov/mmwr/preview/mmwrhtml//mm6424a2.htm.

CDC [2016a]. HIV surveillance report: diagnosis of HIV infection in the United States and Dependent Areas, 2015; vol. 27. Atlanta, GA: U.S. Department of Health and Human Services, Centers for Disease Control and Prevention, National Center for HIV/AIDS, Viral Hepatitis, Sexual Transmitted Diseases and Tuberculosis Prevention, http://www.cdc.gov/hiv/library/reports/hiv-surveillance.html.

CDC [2016b]. Increases in drug and opioid-involved overdose deaths - United States, 2010-2015. MMWR 65:1445-1452, http://dx.doi.org/10.15585/mmwr.mm655051e1.

CDC [2016c]. Occupational HIV transmission and prevention among health care. Atlanta, GA: U.S. Department of Health and Human Services, Centers for Disease Control and Prevention, National Center for HIV/AIDS, Viral Hepatitis, Sexually Transmitted Diseases and Tuberculosis Prevention, https://www.cdc.gov/hiv/workplace/healthcareworkers.html.

CDC [2017]. Viral hepatitis statistics and surveillance. Atlanta, GA: U.S. Department of Health and Human Services, Centers for Disease Control and Prevention, National Center for HIV/AIDS, Viral Hepatitis, Sexually Transmitted Diseases and Tuberculosis Prevention, https://www.cdc.gov/hepatitis/statistics/index.htm.

CFR. Code of Federal Regulations. Washington, DC: U.S. Government Printing Office, Office of the Federal Register.

Clark MM, Warren BA, Hagen PT, Johnson BD, Jenkins SM, Werneburg BL, Olsen KD [2011]. Stress level, health behaviors, and quality of life in employees joining a wellness center. Am J Health Promot 26(1):21-25, http://dx.doi.org/10.4278/ajhp.090821-QUAN-272.

Corneil W, Beaton R, Murphy S, Johnson C, Pike K [1999]. Exposure to traumatic incidents and prevalence of posttraumatic symptomatology in urban fire fighters in two countries. J Occup Health Psych 4(2):131-141, http://dx.doi.org/10.1037/1076-8998.4.2.131.

Corrigan P [2004]. How stigma interferes with mental health care.

Am Psychol 59(7):614-625, http://dx.doi.org/10.1037/0003-066X.59.7.614.

DEA [2015]. DEA issues nationwide alert on fentanyl as threat to health and public safety. News release, March 18, https://www.dea.gov/divisions/hq/2015/hq031815.shtml.

Do AN, Ciesielski CA, Metler RP, Hammett TA, Li J, Fleming PL [2003]. Occupationally acquired human immunodeficiency virus (HIV) infection: national case surveillance data during 20 years of the HIV epidemic in the United States. Infect Control Hosp Epidemiol 24(2):86-96, http://dx.doi.org/10.1086/502178. 
Gerberding JL [1994]. Incidence and prevalence of human immunodeficiency virus, hepatitis $\mathrm{B}$ virus, hepatitis $\mathrm{C}$ virus, and cytomegalovirus among health care personnel at risk for blood exposure: final report from a longitudinal study. J Infect Dis 170(6):1410-1417, http://dx.doi.org/10.1093/infdis/170.6.1410.

Hu DJ, Kane MA, Heymann DL [1991]. Transmission of HIV, hepatitis B virus, and other bloodborne pathogens in health care settings: a review of risk factors and guidelines for prevention. Bull World Health Organ 69(5):623-630, http://www.ncbi.nlm.nih.gov/pmc/articles/PMC2393247/.

Kowdley KV, Wang CC, Welsh S, Roberts H, Brosgart CL [2012]. Prevalence of chronic hepatitis B among foreign-born persons living in the United States by country of origin. Hepatology 56(2):422-433, http://dx.doi.org/10.1002/hep.24804.

Kuhar DT, Henderson DK, Struble KA, Heneine W, Thomas V, Cheever LW, Gomaa A, Panlilio AL, U.S. Public Health Service Work Group [2013]. Updated U.S. Public Health Service guidelines for the management of occupational exposures to human immunodeficiency virus and recommendations for postexposure prophylaxis. Infect Control Hosp Epidemiol 34(9):875-892, http://dx.doi.org/10.1086/672271.

Norwood PJ, Rascati J [2009]. Recognizing and combating fire fighter stress. Penwell/Fire Engineering University, http://www.fireengineering.com/content/dam/fe/online-articles/documents/FEU/FEUNorwoodDec 12.pdf.

Hoge CW, Castro CA, Messer SC, McGurk D, Cotting DI, Koffman RL [2004]. Combat duty in Iraq and Afghanistan, mental health problems, and barriers to care.

N Engl J Med 351:13-22, http://dx.doi.org/10.1056/NEJMoa040603.

Ippolito G, Puro V, Heptonstall J, Jagger J, De Carli G, Petrosillo N [1999]. Occupational human immunodeficiency virus infection in health care workers: worldwide cases through September 1997. Clin Infect Dis 28(2):365-383, http://dx.doi.org/10.1086/515101.

Kroenke K, Spitzer RL [2002]. The PHQ-9: a new depression and diagnostic severity measure. Psychiatry Ann 32(9):509-521, http://dx.doi.org/10.3928/0048-5713-20020901-06.

Leiss JK, Ratcliffe JM, Lyden JT, Sousa S, Orelien JG, Boal WL, Jagger J [2006]. Blood exposure among paramedics: incidence rates from the national study to prevent blood exposure in paramedics. Ann Epidemiol 16(9):720-725, http://dx.doi.org/10.1016/j.annepidem.2005.12.007.

Merchant RC, Nettleton JE, Mayer KH, Becker BM [2009]. Blood or body fluid exposures and HIV postexposure prophylaxis utilization among first responders. Prehosp Emerg Care 13(1):6-13, http://dx.doi.org/10.1080/10903120802471931.

NFPA [2007]. NFPA 1500 Standard on fire department occupational safety and health program. Quincy, MA: National Fire Protection Association. 
NIOSH [2006]. New Orleans Fire Department - New Orleans, Louisiana. Cincinnati, OH: U.S. Department of Health and Human Services, Centers for Disease Control and Prevention, National Institute for Occupational Safety and Health, NIOSH Health Hazard Evaluation Report 2006-0023-3003, https://www.cdc.gov/niosh/hhe/reports/pdfs/2006-0023-3003.pdf.

NIOSH [2011]. Work organization and stress-related disorders, http://www.cdc.gov/niosh/programs/workorg/.

NIOSH [2016]. Fentanyl: preventing occupational exposure to emergency responders. Cincinnati, OH: U.S. Department of Health and Human Services, Centers for Disease Control and Prevention, National Institute for Occupational Safety and Health, https://www.cdc.gov/niosh/topics/fentanyl/default.html.

Roman J [2017]. Chasing a killer. NFPA Journal, January/February, http://www.nfpa.org/news-and-research/publications/nfpa-journal/2017/januaryfebruary-2017/features/opiates.

Spitzer RL, Kroenke K, Williams JBW, Löwe B [2006]. A brief measure for assessing generalized anxiety disorder: the GAD-7. Arch Intern Med 166(10):1092-1097, http://dx.doi.org/10.1001/archinte.166.10.1092.

Suryaprasad AG, White JZ, Xu F, Eichler B-A, Hamilton J, Patel A, Hamdounia SB, Church DR, Barton K, Fisher C, Macomber K, Stanley M, Guilfoyle SM, Sweet K, Liu S, Iqbal K, Tohme R, Sharapov U, Kupronis BA, Ward JW, Holmberg SD [2014]. Emerging epidemic of hepatitis $\mathrm{C}$ virus infections among young nonurban persons who inject drugs in the United States, 2006-2012. Clin Infect Dis 59(10):1411-1419, http://dx.doi.org/10.1093/cid/ciu643.

Vogel DL, Wade NG, Hackler AH [2007]. Perceived public stigma and the willingness to seek counseling: the mediating roles of self-stigma and attitudes toward counseling. J Couns Psychol 54(1):40-50, http://dx.doi.org/10.1037/0022-0167.54.1.40.

Weathers FW, Litz BT, Keane TM, Palmieri PA, Marx BP, Schnurr PP [2013]. The PTSD checklist for DSM-5 (PCL-5). National Center for PTSD, http://www.ptsd.va.gov. 
Keywords: North American Industry Classification System (NAICS) 922120 (Fire

Protection); West Virginia; Firefighting, First Responders, Stress, Mental Health, Opioid

Overdose, Naloxone, Bloodborne Pathogens, Drug, Needlestick, Opioid 
The Health Hazard Evaluation Program investigates possible health hazards in the workplace under the authority of the Occupational Safety and Health Act of 1970 (29 U.S.C. § 669(a) (6)). The Health Hazard Evaluation Program also provides, upon request, technical assistance to federal, state, and local agencies to investigate occupational health hazards and to prevent occupational disease or injury. Regulations guiding the Program can be found in Title 42, Code of Federal Regulations, Part 85; Requests for Health Hazard Evaluations (42 CFR Part 85).

\section{Disclaimer}

The recommendations in this report are made on the basis of the findings at the workplace evaluated and may not be applicable to other workplaces.

Mention of any company or product in this report does not constitute endorsement by NIOSH.

Citations to Web sites external to NIOSH do not constitute NIOSH endorsement of the sponsoring organizations or their programs or products. NIOSH is not responsible for the content of these Web sites. All Web addresses referenced in this document were accessible as of the publication date.

\section{Acknowledgments}

Statistical Support: Guadalupe (Pita) Gomez

Desktop Publisher: Shawna Watts

Editor: Ellen Galloway

\section{Availability of Report}

Copies of this report have been sent to the employer, employees, and Union at the facility. The state and local health department and the Occupational Safety and Health Administration Regional Office have also received a copy. This report is not copyrighted and may be freely reproduced.

\section{Recommended citation for this report:}

NIOSH [2017]. Evaluation of fire fighters' mental health symptoms and exposure to traumatic events, job stress, and bloodborne pathogens. By Wiegand DM, Chiu S. Cincinnati, OH: U.S. Department of Health and Human Services, Centers for Disease Control and Prevention, National Institute for Occupational Safety and Health, Health Hazard Evaluation Report 2017-0021-3293, https://www.cdc.gov/niosh/hhe/reports/pdfs/2017-0021-3293.pdf. 
Delivering on the Nation's promise:

Promoting productive workplaces through safety and health research

To receive NIOSH documents or more information about occupational safety and health topics, please contact NIOSH:

Telephone: 1-800-CDC-INFO (1-800-232-4636)

TTY: 1-888-232-6348

CDC INFO: www.cdc.gov/info

or visit the NIOSH Web site at www.cdc.gov/niosh

For a monthly update on news at $\mathrm{NIOSH}$, subscribe to $\mathrm{NIOSH}$ eNews by visiting www.cdc.gov/niosh/eNews. 